\title{
Mirizzi syndrome from type I to Vb: a single center experience
}

\author{
Mauricio Gonzalez-Urquijo ${ }^{1}$ (D), Gerardo GII-Galindo 2 (D), Mario Rodarte-Shade ${ }^{1}$ (D) \\ ${ }^{1}$ Department of Surgery, Tecnologico de Monterrey, School of Medicine and Health Sciences, Monterrey, Mexico \\ ${ }^{2}$ Clinic of Surgery, Metropolitano Hospital, Monterrey, Mexico
}

\begin{abstract}
Objective: The present study describes a cohort of patients diagnosed with Mirizzi syndrome from type I to Vb, over a period of four years. It aimed to identify diagnostic and management pitfalls of Mirizzi syndrome, as well as their concomitant cholecystobiliary or cholecystoenteric fistulas.

Material and Methods: We retrospectively reviewed all electronic medical records of patients who underwent surgery for Mirizzi syndrome at a single institution.

Results: Twenty-two patients (0.6\%) were diagnosed with Mirizzi syndrome. Most of the patients were females ( $n=19,86.3 \%)$. Mean age was 43.8 years (range: 21-71 years). Ultrasound was performed in all (100\%) patients. Six (27.2\%) patients had a CT scan and six (27.2\%) patients had endoscopic retrograde cholangiopancreatography. Overall preoperative diagnosis was achieved on $36.6 \%(n=8)$ of the patients. There were the same total and partial cholecystectomies, accounting for ten (45.5\%) cases each, one hepaticojejunostomy with cholecystectomy (4.5\%), and one enterolithotomy (4.5\%). Laparoscopic cholecystectomy was attempted in $15(68.1 \%)$ patients, with conversion to open surgery in $93.3 \%(n=14)$ of the patients. An open approach was made in five (22.7\%) cases. Four (18.1\%) patients were reported as MS type I, both types II and III each account for $22.7 \%$ ( $n=5)$ of the cases, there was only one (4.5\%) patient with type IV, and seven (31.8\%) patients with type V.
\end{abstract}

Conclusion: There are limited studies of patients with Mirizzi syndrome, including type $V$ classification, and when this syndrome is suspected, a preoperative diagnosis should be made to avoid bile duct injuries or lesions to adjacent organs.

Keywords: Biliary disease, cholecystectomy, cholecystobiliary fistula, cholecystoenteric fistula, gallstone disease, mirizzi syndrome

Cite this article as: Gonzalez-Urquijo M, Gl-Galindo G, Rodarte-Shade M. Mirizzi syndrome from type I to Vb: a single center experience. Turk J Surg 2020; 36 (4): 399-404

\section{Corresponding Author}

Mauricio Gonzalez-Urquijo

E-mail: mauriciogzzu@gmail.com

Received: 01.01.2020

Accepted: 29.01.2020

Available Online Date: 29.12.2020

O Copyright 2020 by Turkish Surgical Society Available online at www.turkjsurg.com

DOI: $10.47717 /$ turkjsurg.2020.4676

\section{INTRODUCTION}

Gallstone disease is a common digestive disease with an estimated prevalence of $10-20 \%$ in adults in developed countries $(1,2)$. This disorder occurs when there is an imbalance in the composition of the bile, resulting in precipitation of one or more of its components (3). Mirizzi syndrome (MS) is an uncommon phenomenon, with an incidence of $0.7-2.9 \%$ of all cholecystectomies $(2,4,5)$. Pablo Luis Mirizzi first described this entity in 1948, defining it as an obstruction of the common hepatic duct (CHD) or common bile duct (CBD) by the compression of an impacted stone in the neck of the gallbladder or cystic duct, causing obstructive jaundice, and leading occasionally to fistulization to the bile duct or surrounding organs $(6,7)$.

The treatment of MS is either by laparoscopy or by open approach, with high conversion rates with the former, consisting of partial or complete cholecystectomy with or without common bile duct exploration, and sometimes bilioenteric anastomosis may be performed (8).

MS is a severe disease, and preoperative detection or intraoperative recognition of MS is essential for the surgeon to reduce the risk of operative complications, being the most common bile duct injury and residual stones (1).

The present study reviewed the experience of a single center with Mirizzi syndrome over a period of 4 years. It aimed to identify diagnostic and management pitfalls of Mirizzi syndrome, as well as their concomitant cholecystobiliary or cholecystoenteric fistulas.

This study was approved by IRB, Tecnologico de Monterrey, under the number 098. 


\section{MATERIAL and METHODS}

From 2014 to 2018, 22 consecutive patients underwent surgery for MS at a single teaching institution. We searched the surgical database for all patients diagnosed postoperatively with MS, and retrospectively reviewed all electronic medical records. Patient demographics, clinical characteristics, diagnostic method, surgical procedures, outcomes, and follow-up were all documented and organized. All patients underwent physical examination, laboratory testing, and ultrasonographic (US) or computed tomography (CT) evaluation of the gallbladder. All the cases diagnosed were based on preoperative investigations or intraoperative findings. Beltran and Csendes modified classification (9). was followed to categorize patients as the diagnostic criteria. Laparoscopic cholecystectomy under general anesthesia with a standard four-port technique was attempted in most patients. Conversion to open surgery was left to the discretion of the surgeon. When dense adhesions to adjacent organs and impacted stones in Hartmann's pouch rendered access to Calot's triangle difficult, a fundus-first dissection technique was applied, and subtotal cholecystectomy was performed. All patients were seen in the outpatient clinic within the first month of the initial surgery, and all patients had a follow-up of up of at least six months after surgery. Patients were examined clinically, and liver function tests were evaluated for each follow-up visit.

This manuscript was approved by Tecnologico de Monterrey ethics committee and institutional review board (IRB) number 098, and was therefore performed in accordance with the ethical standards laid down in the 1964 Declaration of Helsinki and its later amendments. All patients provided informed consent to participate in the surveillance protocols.

Data were reported as mean, range, or percentages for continuous variables and frequencies and percentages for categorical variables. Data analysis was performed, with a combination of Excel 16.0 (Microsoft Corporation, United States) and R software 3.4 (R Core Team, New Zealand).

\section{RESULTS}

A total of 3556 cholecystectomies were performed during the study period. Twenty-two patients (0.6\%) were diagnosed with Mirizzi syndrome. Most of the patients were females $(n=19$, $86.3 \%)$, with only three (13.6\%) male patients. Mean age was 43.8 years (range: $21-71$ years), four (18.1\%) patients had diabetes mellitus (DM) concomitantly with systemic arterial hypertension (SAH), two (9\%) patients had only DM, and one (4.5\%) patient had only SAH. One (4.5\%) patient had hypothyroidism, and one (4.5\%) patient was asthmatic. All patients had a history of abdominal pain of 10.9 months on average (range 1-76 months), with a mean time of exacerbation of abdominal pain before their surgical treatment of 6 days (range: 1-21 days). Thirteen (59\%) patients were jaundiced at presentation. Liver function tests were altered in almost all patients $(n=18,81.8 \%)$ (Table 1$)$.

\begin{tabular}{|c|c|}
\hline Laboratories values & Mean (Range) \\
\hline $\mathrm{WBC} \times 10^{9} / \mathrm{L}$ & $12(7-15.6)$ \\
\hline Total Bilirubin (mg/dL) & $5.41(0.51-14.29)$ \\
\hline Direct Bilirubin (mg/dL) & $4.03(0.23-11.88)$ \\
\hline Indirect Bilirubin (mg/dL) & $1.36(0.2-3.6)$ \\
\hline AST (U/I) & $145.71(11-500)$ \\
\hline ALT (U/I) & $196.28(8-479)$ \\
\hline $\mathrm{AP}(\mathrm{U} / \mathrm{I})$ & $400(75-1236)$ \\
\hline GGT (U/I) & $521(23-1297)$ \\
\hline
\end{tabular}

US was the initial imaging study performed in all patients. It revealed gallstones and features of acute cholecystitis in every case (100\%), plus a single (4.6\%) patient had choledocholithiasis. Mean size of gallbladder wall thickening was $4.86 \mathrm{~mm}$ (range: 1.2-10 mm), and mean diameter size of CBD was 8.21 mm (range: 3.17-14 mm). Ten (45.4\%) had an impacted stone on the Hartman pouch or cystic duct, and in only six (27.2\%) patients, a CT scan was ordered for suspicious of cholecystoenteric fistula, finding on $66 \%(n=4)$ of the patients neumobilia and a sigmoid gallstone ileus on one (16.6\%) patient. Endoscopic retrograde cholangiopancreatography (ERCP) was performed in six (27.2\%) cases, performing sphincterotomy for bile duct decompression, placing bile duct stents at the end of the procedure. The diagnosis of MS was made in 50\% of these patients by direct identification of a fistula.

Postoperatively, four (18.1\%) patients were reported as type I, both types II and III each account for $22.7 \%(n=5)$ of the cases, there was only one (4.5\%) patient with type IV, treated with an open cholecystectomy and Roux-en-Y hepaticojejunostomy, and the remaining seven (31.8\%) patients were found to have various types of cholecystoenteric fistulas (type $\mathrm{V}$ ). We had the same number of patients with cholecystoduodenal and cholecystocolonic fistulas, accounting for three patients with each type of fistula. Of the three patients with cholecystoduodenal fistula, two were treated with a graham patch on the duodenum and primary closure of the CBD, and one was treated with choledochoplasty with a gallbladder flap and primary closure of the duodenum. Of the patients who presented with a cholecystocolonic fistula, a colostomy at the site of the fistula was performed on one patient, with primary closure of the CBD, another was treated with primary closure of the transverse colon and $T$ tube insertion on the CBD, and the third patient was treated with enterolithotomy alone, for an intestinal obstruction due to a sigmoid gallstone ileus. The remaining patient with MS type $\mathrm{V}$ presented a gastrobiliary fistula on the lesser curvature, 


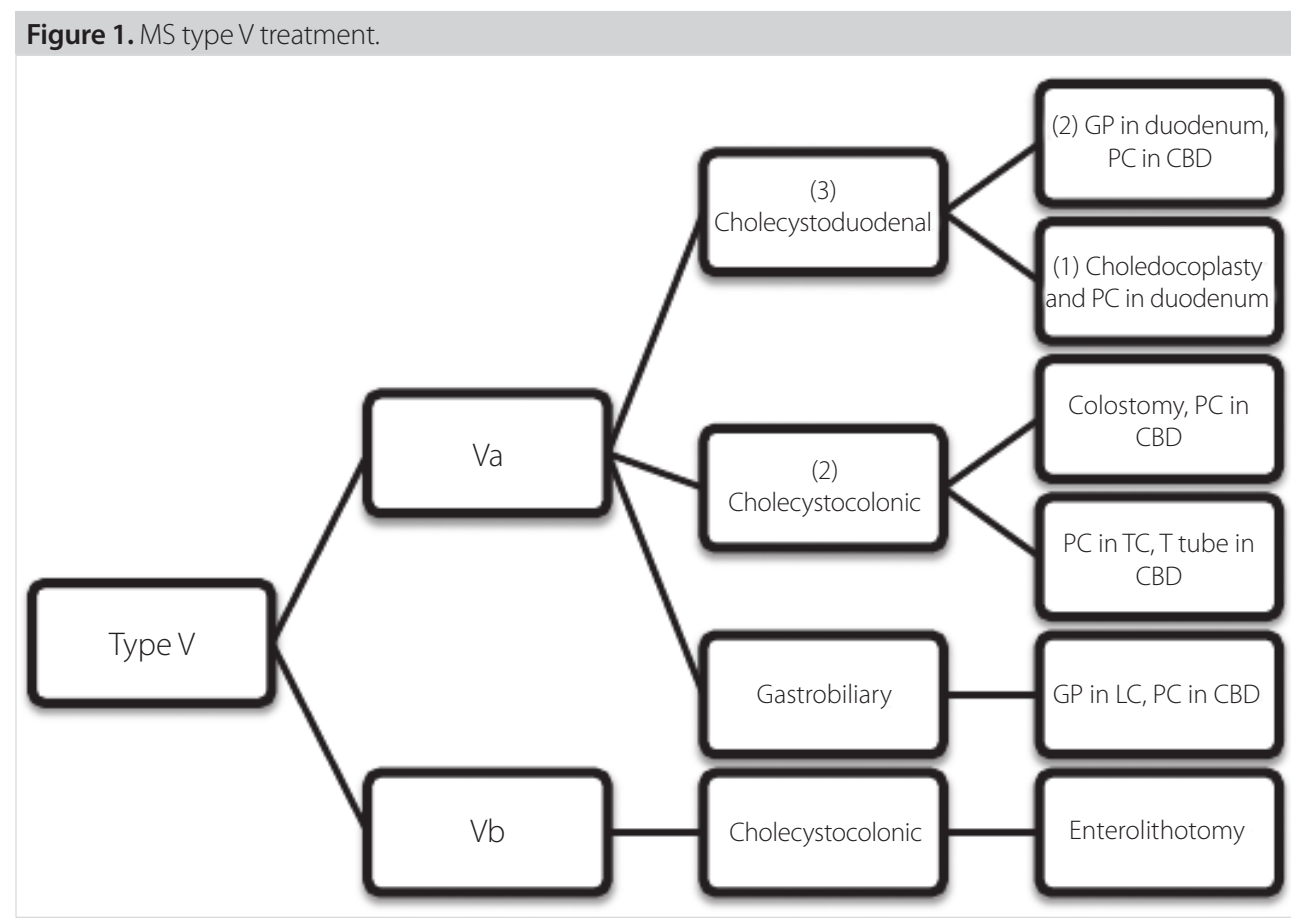

Table 2. Type of surgical treatment

\begin{tabular}{|l|c|c|c|c|c|c|}
\hline Total $(\mathbf{n}=\mathbf{2 2})$ & Type I $(\mathbf{n}=\mathbf{4})$ & Type II $(\mathbf{n}=\mathbf{5})$ & Type III $(\mathbf{n}=\mathbf{5})$ & Type IV $(\mathbf{n}=\mathbf{1})$ & Type Va $(\mathbf{n}=\mathbf{6})$ & Type Vb $(\mathbf{n}=\mathbf{1})$ \\
\hline Open $(n=5)$ & - & $2+$ & 2 & - & 1 & - \\
\hline Laparoscopic + Conversion $(n=14)$ & 3 & $3\left(2^{*}+, 1^{*}\right)$ & $3^{*}+$ & - & $5\left(2^{*}, 3+\right)$ & - \\
\hline Laparoscopic $(n=1)$ & 1 & - & - & - & - \\
\hline Hepaticojejunostomy $(n=1)$ & - & - & - & 1 & - \\
\hline Enterolitotomy $(n=1)$ & - & - & - & - & - \\
\hline *, T-tube; +: partial cholecystectomy.
\end{tabular}

treated with primary closure, and an omental patch on the site of the fistula in the stomach, a T tube was placed with a reconstruction of the CBD (Figure 1).

Overall, there were equal number of total and partial cholecystectomies, accounting for ten (45.5\%) cases each, one hepaticojejunostomy with cholecystectomy (4.5\%), and one enterolithotomy (4.5\%). Laparoscopic cholecystectomy was attempted in 15 (68.1\%) patients, and because of difficult dissection and misleading anatomy in Calot's triangle, conversion to open surgery was achieved in $93.3 \%(n=14)$ of the patients. An open technique was used as the initial procedure in five (22.7\%) cases. A trans-operative cholangiogram (TOC) was attempted in $76.1 \%(n=16)$ of the cases where a cholecystectomy was performed $(n=21)$, being conclusive in 13 (81.25\%) patients with evidence of either cholecystobiliary or cholecystoenteric fistula. In eight (38\%) patients, a T-tube was placed on the common bile duct, and all patients had a tube drain left in the subhepatic space, which was removed within a mean of 5 days (range: 3-10 days) (Table 2).
Overall procedure-related morbidity was $13.6 \%(n=3)$. Two patients developed bile leak, and one patient had a remaining stone. All were treated with ERCP and placement of biliary stents, removing them on postoperative week six, with an outstanding outcome. Mortality was accounted for $9 \%(n=2)$ of the patients. In the remaining patients, mean length of hospital stay (LOS) was 8 days (range: 2-30 days). Final histopathology revealed chronic cholecystitis in all (100\%) patients, except one 51-year-old patient, who presented associated adenocarcinoma of the gallbladder and treated with adjuvant therapy. All patients were followed up in the ambulatory clinic for at least 12 months, with a mean period of 23 months (range: 1236 months), all symptoms free with normal liver function tests, except the patient treated with hepaticojejunostomy anastomosis, who had a persistent elevation of serum alkaline phosphatase and developed a mild episode of cholangitis treated successfully with antibiotics, with no further complications. The patient with gallbladder adenocarcinoma stage I did not need 
any further surgery, and 12 months after his initial surgery, he is currently alive with oncology follow up.

\section{DISCUSSION}

The MS incidence of $0.6 \%$ in the present series correlates with the $0.7 \%-2.53 \%$ stated in the literature (10-12). This syndrome develops in patients with longstanding gallstone disease, with a female predominance, with this series supporting this majority. We had a mean age of 43.8 years, making it inferior to the ones reported in the literature that ranges from 48 to 61 years (9). The main confront in the management of MS is in accomplishing a precise preoperative diagnosis, with rates ranging from $8 \%$ to $62 \%$ of obtaining an accurate image identification of this condition, if this is not accomplished, the incidence of bile duct injuries could be as high as $17 \%(13,14)$. Several image studies can be used for achieving this; US is the most common modality used for the diagnosis of gallstones; however, it has limited sensitivity (48\%). CT may show dilation of the biliary tree and the CBD, with low sensitivity for identifying stones at these sites, but it may exclude a malignancy in the porta hepatis area or the liver. Magnetic resonance cholangiopancreatography (MRCP), is a non- invasive imaging technique with a 50\% diagnostic accuracy rate, having the advantage of avoiding the complications associated with ERCP, which is considered the gold standard for diagnosing this disorder with a mean sensitivity rate of $76.2 \%$, with technical limitations in $5 \%$ to $10 \%$ of the cases, including inaccessibility to the bile ducts and incomplete filling of the ducts because of tight strictures, additionally it is not exempt from complications such as pancreatitis, cholangitis, and residual stones $(4,14-16)$. Since, we lack MRCP in our institution, a preoperative diagnosis was challenging to attain, and even though almost half of our patients had a US with an impacted stone, a direct compression to the hepatic or common bile duct was difficult to visualize, therefore in patients with high suspicious of MS, a ERCP or a CT scan was ordered, visualizing a fistula in three patients with the former study, and neumobilia in four patients with the latter. We achieved an overall preoperative diagnosis of $36.6 \%$ in our patients, with nearly the same rate as the series of Greiasov et al. (17) who accomplished a preoperative diagnosis rate of $27 \%$ in a large cohort of 284 patients.

An often-absent sign of identification of this disease and almost pathognomonic is neumobilia (18). This sign was seen in $66 \%$ of our patients who had CT $(n=6)$, higher than the series from Li et al. (19) where this sign was seen in $33 \%$ of the CTs. We opted to treat our three patients with cholecystoduodenal fistula with primary closure and choledochoplasty in the CBD, performing primary closure of the duodenum with or without over sewing an omental patch, with satisfactory results. We had the same number of patients with cholecystoduodenal and cholecystocolonic fistulas, similar to the study of Pradeep et al. (20), who identified the duodenum and the colon, as their two most common or- gans involved. On the patients where the colon was involved, we performed on partial cholecystectomies. On one patient, we performed primary closure of the transverse colon and $\mathrm{T}$ tube insertion on the CBD, on a second patient, a colostomy was achieved with intestinal reconnection auspiciously implemented 20 weeks later, and on a third patient, a gallstone ileus on the sigmoid colon along with a cholecystocolonic fistula was faced, opting for a conservative management because of a low functional reserve, achieving only an enterolithotomy and antibiotic therapy with positive outcomes. This unusual site of impaction of the stone is exceptionally infrequent, occurring only in $8 \%$ of all patients with gallstone ileus (20-21).

There are two popular classifications well accepted for this condition. The first one is the one proposed in 1982 by McSherry and colleagues (22), categorizing MS into two types: type I, characterized by external compression of the adjacent common hepatic duct; and, type II, where a pressure necrosis of the common bile duct results in a cholecystocholedochal fistula. The second classification was developed seven years later by Csendes et al. (10) reclassifying MS in IV types, being type I lesions with external compression of the common bile duct, type II lesions where a cholecystocholedochal fistula is present with erosion of less than one-third of the circumference of the bile duct, distinguishing it from type III lesions where the fistula involves up to two-thirds of the duct circumference and finally type IV lesions where there is complete destruction of the bile duct. Almost two decades later, Csendes added an additional type to this classification, validated by Beltran (9), supplementing a type $\mathrm{Va}$ and $\mathrm{Vb}$, corresponding with an MS with a cholecystoenteric fistula without and with a gallstone ileus respectively. Our most common type of MS was the type V, following equally by type II and III, and because MS type I does not involve a fistula, we think numerous MS type I passed undiagnosed, categorizing them as hydropic gallbladder or acute cholecystitis.

Beltran et al. (9) have supported that conventional surgery for patients with suspected MS is safer in most institutions of developing countries where access to diagnostic equipment, such as MRCP, ERCP, intraoperative ultrasonography, or choledoscopy are not available. Laparoscopic management can be performed especially in MS type I with a visualized cystic duct, and only cholecystectomy either total or partial is needed. However, patients with the other four types of MS always require bile duct exploration with intraoperative cholangiogram and common bile duct reconstruction through simple closure of the fistula or T-tube insertion, leaving bilioenteric anastomosis for patients with type IV (15). Of all surgeries performed at our hospital, only one patient with MS type I was completed by a laparoscopic approach; hence, we had a conversion rate of almost 100\%. In patients with MS type II and III; a T tube was placed on $60 \%$ of them, with the remaining patients treated with primary closure or choledochoplasty. Almost all of these patients had adequate results, except for 
our two fatalities, being two elderly and diabetic patients, treated with T-tube placement and without T tube placement, MS type II and MS type III respectively, presenting bile leakage treated at first with ERCP and biliary stent placement, reintervening both cases with abdominal washout and drainage placement with no favorable evolution. The patients died 45 days and 80 days after the initial surgery due to abdominal sepsis. Moreover, a bilioenteric anastomosis was achieved for our patient with MS type IV with worthy results.

The clinical diagnosis of MS is challenging to attain since there are no pathognomonic symptoms for presentation (4). Thus, obtaining a preoperative diagnosis is defiant, because signs like jaundice, acholia, or choluria may be lacking, adding that 20\% to $40 \%$ of the patients have normal serum bilirubin levels (23). In our series, $18.1 \%$ of our patient's laboratory values were with standard parameters, and 59\% of the patients presented with jaundice, differently from the series of Kwon et at. (23) where only 33\% presented with this sign.

In their systematic review, Antoniou et al. (8) have stated that the outcome of laparoscopic treatment of MS is not inferior to that of open surgery; however, it carries a meaningful conversion rate of $41 \%$, with complications rates of $20 \%$ and a mean hospital stay of 8 days. In another study of 27 MS, Chowbey et al. (24) have reported a 22\% conversion rate. This contrasts with our experience, where we had a much higher conversion rate corresponding for 93.3\% of all laparoscopic approaches, with a similar complication rate of $22.7 \%$ and the same mean hospital LOS of 8 days. We believe it is essential for surgeons to prevent CBD injury and manage the fistula and CBD obstruction adequately. Thus, if an obliterated Calot's triangle and surrounding adhesions are encountered trans operatively, it is obligatory to obtain a cholangiogram, and if a cholecystobiliary or cholecystoenteric fistula is visualized, conversion to open cholecystectomy may be preferred, nonetheless, in inexperienced laparoscopic hands, an endoscopic approach may be feasible and secure.

All our patients' final histopathology results were benign for malignancy except for one male mid-age patient, who presented a final diagnosis of adenocarcinoma. Redaelli et al. (25) have stated an association of MS with gallbladder cancer in $28 \%$ of their cases, in contrast with an Indian study by Kumar et al. (26) where only $5 \%$ of the patients with MS presented concomitantly gallbladder cancer, making it similar to our series.

In summary, we believe stronger importance should be given to the preoperative diagnosis of this syndrome, and when doubting after ultrasonography is performed, an MRCP or ERCP should be achieved to prevent severe complications during surgery. Nowadays, there is no consensus for the right treatment for each type of MS, and outstanding long-term outcomes can be anticipated by using a variety of operative techniques to address Calot's triangle, the cystic duct stump, and the biliary or enteric fistula.
Although signs and symptoms are not precise, the primary clinical manifestation is jaundice with a predominantly obstructive laboratory pattern, along with right upper quadrant pain, making it difficult to distinguish it from cholangitis. This is one of the few case series describing MS, including the type V classification, contributing with our experience to the existing literature regarding this unusual and controversial syndrome.

Ethics Committee Approval: The approval for this study was obtained from Hospital Zembrano Hellion Ethics Committee (Decision No: 098, Date: 18.11.2019).

Informed Consent: Written informed consent was obtained from patient who participated in this case.

Peer-review: Externally peer-reviewed.

Author Contributions: Concept - M.G.U.; Design - G.G.G.; Supervision M.G.U.; Materials - M.G.U.; Data Collection and/or Processing - M.G.U.; Analysis and/or Interpretation - M.G.U.; Literature Search - M.G.U.; Writing Manuscript - M.G.U.; Critical Reviews - G.G.G., M.R.S.

Conflict of Interest: No conflict of interest was declared by the authors. Financial Disclosure: The authors declared that this study has received no financial support.

\section{REFERENCES}

1. Lammert F, Gurusamy K, Ko CW, Miquel J-F, Méndez-Sánchez N, Portincasa P, et al. Gallstones. Nat Rev Dis Prim (Internet) 2016 Apr 28;2: 16024. Available from: http://dx.doi.org/10.1038/nrdp.2016.24 [CrossRef]

2. Cui Y, LiU Y, Li Z, Zhao E, Zhang H, Cui N. Appraisal of diagnosis and surgical approach for Mirizzi syndrome. ANZ J Surg 2012; 82(10): 70813. [CrossRef]

3. Lee JYJ, Keane MG, Pereira S. Diagnosis and treatment of gallstone disease. Practitioner 2015; 259(1783): 2,15-19. [CrossRef]

4. Erben Y, Benavente-Chenhalls LA, Donohue JM, Que FG, Kendrick ML, Reid-Lombardo KM, et al. Diagnosis and treatment of Mirizzi syndrome: 23-year mayo clinic experience. J Am Coll Surg (Internet) 2011; 213(1): 114-9. Available from: http://dx.doi.org/10.1016/j.jamcollsurg.2011.03.008 [CrossRef]

5. Lledó JB, Barber SM, Ibañez JC, Torregrosa AG, Lopez-Andujar R. Update on the diagnosis and treatment of Mirizzi syndrome in laparoscopic era: Our experience in 7 years. Surg Laparosc Endosc Percutaneous Tech 2014; 24(6): 495-501. [CrossRef]

6. Mirizzi PL. Hepatic duct syndrome. J Int Chir 1948; 8: 731-77. [CrossRef]

7. Seah WM, Koh YX, Cheow PC, Chow PKH, Chan CY, Lee SY, et al. A retrospective review of the diagnostic and management challenges of Mirizzi syndrome at the Singapore General Hospital. Dig Surg 2018; 35(6): 491-7. [CrossRef]

8. Antoniou SA, Antoniou GA, Makridis C. Laparoscopic treatment of Mirizzi syndrome: A systematic review. Surg Endosc Other Interv Tech 2010; 24(1): 33-9. [CrossRef]

9. Beltran MA, Csendes A, Cruces KS. The relationship of Mirizzi syndrome and cholecystoenteric fistula: Validation of a modified classification. World J Surg 2008; 32(10): 2237-43. [CrossRef]

10. Csendes A, Diaz JC, Burdiles P, Maluenda F, Nava O. Mirizzi syndrome and cholecystobiliary fistula: A unifying classification. Br J Surg 1989; (11): 1139-43. [CrossRef] 
11. Tan KY, Chng HC, Chen CYY, Tan SM, Poh BK, Hoe MNY. Mirizzi syndrome: Noteworthy aspects of a retrospective study in one centre. ANZ J Surg 2004; 74(10): 833-7. [CrossRef]

12. Al-Akeely MHA, Alam MK, Bismar HA, Khalid K, Al-Teimi I, Al-Dossary NF. Mirizzi syndrome: Ten years experience from a teaching hospital in Riyadh. World J Surg 2005; (12): 1687-92. [CrossRef]

13. Lai ECH, Lau WY. Mirizzi syndrome: History, present and future development. ANZ J Surg 2006; 76(4): 251-7. [CrossRef]

14. Beltrán MA. Mirizzi syndrome: History, current knowledge and proposal of a simplified classification. World J Gastroenterol 2012; 18(34): 4639-50. [CrossRef]

15. Solis-Caxaj CA. Mirizzi syndrome: Diagnosis, treatment and a plea for a simplified classification. World J Surg 2009; 33(8): 1783-4. [CrossRef]

16. Chen H, Siwo EA, Khu M, Tian Y. Current trends in the management of Mirizzi Syndrome A review of literature. Medicine (Baltimore) (Internet) 2018; 97(4): e9691. Available from: https://pubmed.ncbi.n/m.nih gov/29369192/[CrossRef]

17. Greiasov VI, Perfilev W, Shchepkin SP, Petrichenko AV, Sivokon' NI, Chuguevskii VM. Diagnostics and surgical tactics for Mirizzi syndrome. Khirurgiia (Sofiia) 2008; (11): 31-4. [CrossRef]

18. Costi R, Randone B, Violi V, Scatton O, Sarli L, Soubrane O, et al. Cholecystocolonic fistula: facts and myths. A review of the 231 published cases. J Hepatobiliary Pancreat Surg 2009; 16(1): 8-18. [CrossRef]

19. Li X, Zhao X, Zheng P, Kao X-M, Xiang X-S, Ji W. Laparoscopic management of cholecystoenteric fistula: A single-center experience. J Int Med Res (Internet) 2017; 45(3): 1090-7. Available from: http://journals. sagepub.com/doi/10.1177/0300060517699038 [CrossRef]
20. Chowbey PK, Bandyopadhyay SK, Anil S, Rajesh K, Vandana S, Manish B. Laparoscopic management of cholecystoenteric fistulas. J Laparoendosc Adv Surg Tech 2006; 16(5): 453-6. Available from: http://dx.doi. org/10.1016/S0976-0016(11)60090-2. [CrossRef]

21. González-Urquijo M, Hinojosa-Gonzalez DE, Quevedo-Fernandez E. Gallstone ileus of the sigmoid colon caused by cholecystocolonic fistula: A case report. Ann Med Surg 2018; 31: 25-8. [CrossRef]

22. McSherry CK, Ferstenberg HVM. The Mirizzi syndrome: suggested classification and surgical therapy. Surg Gastroenterol 1982; 1: 219-225. [CrossRef]

23. Kwon AH, Inui H. Preoperative diagnosis and efficacy of laparoscopic procedures in the treatment of Mirizzi syndrome. J Am Coll Surg 2007; 204(3): 409-15. [CrossRef]

24. Chowbey PK, Sharma A, Mann V, Khullar R, Baijal M, Vashistha A. The management of Mirizzi syndrome in the laparoscopic era. Surg Laparosc Endosc Percutan Tech 2000; 10(1): 11-4. [CrossRef]

25. Redaelli CA, Büchler MW, Schilling MK, KrähenbühI L, Ruchti C, Blumgart LH, et al. High coincidence of Mirizzi syndrome and gallbladder carcinoma. Surgery 1997; 121(1): 58-63. [CrossRef]

26. Kumar A, Senthil G, Prakash A, Behari A, Singh RK, Kapoor VK, et al. Mirizzi's syndrome: lessons learnt from 169 patients at a single center. Korean J Hepato-Biliary-Pancreatic Surg 2016; 20(1): 17. Available from: https://synapse.koreamed.org/DOlx.php?id=10.14701/ kjhbps.2016.20.1.17 [CrossRef]

\title{
OLGU SERISI-ÖZET
}

Turk J Surg 2020; 36 (4): 399-404

\section{Tip I'den Vb'ye Mirizzi Sendromu: tek merkez deneyimi}

\author{
Mauricio Gonzalez-Urquijo ${ }^{1}$, Gerardo Gıl-Galindo ${ }^{2}$, Mario Rodarte-Shade ${ }^{1}$ \\ ${ }^{1}$ Tecnologico de Monterrey Tıp ve Sağlık Bilimleri Fakültesi, Cerrahi Anabilim Dalı, Monterrey, Meksika \\ ${ }^{2}$ Metropolitano Hastanesi, Cerrahi Kliniği, Monterrey, Meksika
}

\section{ÖZET}

Giriş ve Amaç: Bu çalışma, dört yıllık bir süre boyunca tip I'den Vb'ye Mirizzi sendromu (MS) tanısı konan bir hasta grubunu içermektedir. Mirizzi sendromunun tanı ve yönetim güçlüklerinin yanı sıra eşlik eden kolesistobiliyer ve kolesistoenterik fistülleri tanımlamayı amaçlamaktadır.

Gereç ve Yöntem: Tek bir kurumda Mirizzi sendromu nedeniyle ameliyat edilen hastaların tüm elektronik tıbbi kayıtlarını retrospektif olarak inceledik.

Bulgular: Yirmi iki hastaya $(\% 0,6)$ Mirizzi sendromu tanısı kondu. Hastaların çoğu kadındı $(n=19, \% 86,3)$. Ortalama yaş 43,8 idi (aralık: $21-71$ yaş). Tüm hastalara $(\% 100)$ ultrason yapıldı. Altı hastada $(\% 27,2)$ BT taraması, altı hastada $(\% 27,2)$ endoskopik retrograd kolanjiyopankreatografi uygulandı. Preoperatif tanı hastaların \%36,6'sında $(n=8)$ sağlandı. Her birinde onar olgunun $(\% 45,5)$ olduğu total ve parsiyel kolesistektomi, bir $(\% 4,5)$ kolesistektomi ile hepatikojejunostomi ve bir de $(\% 4,5)$ enterolitotomi uygulandı. On beş $(\% 68,1)$ hastada laparoskopik kolesistektomi ile başlandı ve hastaların \%93,3'ünde $(n=14)$ açık cerrahiye dönüşüm yapıldı. Beş $(\% 22,7)$ olguda doğrudan açık cerrahi bir yaklaşım uygulandı. Dört $(\% 18,1)$ hasta MS tip I idi. Tip II ve III, olguların $\% 22,7$ 'sini $(n=5)$ oluştururken, tip IV olan sadece bir $(\% 4,5)$ ve Tip V'li ise yedi hasta $(\% 31,8)$ vardı.

Sonuç: Mirizzi sendromlu hastaların tip V sınıflandırması dahil sınırlı sayıda çalışmaları vardır ve bu sendromdan şüphelenildiğinde, safra kanalı yaralanmalarını veya komşu organlara lezyonları önlemek için ameliyat öncesi tanı konulmalıdır.

Anahtar Kelimeler: Safra hastalığı, kolesistektomi, kolesistobiliyer fistül, kolesistoenterik fistül, safra taşı hastalığı, Mirizzi sendromu

Doi: $10.47717 /$ turkjsurg.2020.4676 